\title{
EPIDEMIOLOGICAL PROFILE OF SERIOUS MALARIA IN NEWBORNS AND ADOLESCENTS SERVED IN 2016 IN A REFERENCE HOSPITAL IN THE STATE OF AMAPÁ, AMAZON REGION, BRAZIL
}

\section{ORIGINAL ARTICLE}

BRITO, Maysa Vasconcelos de ${ }^{1}$, FRANÇA, Ana Maria Braga da Silva², FECURY, Amanda Alves ${ }^{3}$, OLIVEIRA, Euzébio de ${ }^{4}$, DENDASCK, Carla Viana ${ }^{5}$, DIAS, Cláudio Alberto Gellis de Mattos ${ }^{6}$

BRITO, Maysa Vasconcelos de. Et al. Epidemiological profile of serious malaria in newborns and adolescents served in $\mathbf{2 0 1 6}$ in a reference hospital in the State of Amapá, Amazon Region, Brazil. Revista Científica Multidisciplinar Núcleo do Conhecimento. Year 05, Ed. 06, Vol. 12, pp. 05-23. June 2020. ISSN:2448-0959, Access link in: https://www.nucleodoconhecimento.com.br/health/serious-malaria, DOI: 10.32749/nucleodoconhecimento.com.br/health/serious-malaria

\section{ABSTRACT}

The present study took into account not only Plasmodium falciparum infections that are commonly advocated as the main cause of severe malaria, but the complications related to Plasmodium vivax have been carefully described. The objective of this article was to identify the epidemiological, clinical and laboratory profile of severe malaria in patients attended at the Child and Adolescent Hospital in Macapá -

\footnotetext{
${ }^{1}$ Biomedical, PhD in Topical Diseases, Professor and researcher College Estácio of Sá, Macapá.

${ }^{2}$ Biomedical, Technician at Children's and Adolescents Hospital (Macapá - Amapá).

${ }^{3}$ Biomedical, PhD in Topical Diseases, Professor and researcher of the Course of Medicine at the Macapá Campus and the Postgraduate Program in Health Sciences (PPGCS), Federal University of Amapá (UNIFAP).

${ }^{4}$ Biologist, Doctor in Topical Diseases, Professor and researcher of the Education Course Physics, Federal University of Pará (UFPA).

${ }^{5}$ Theologian, PhD in Psychoanalysis, researcher at the Research and Studies Center Advanced (CEPA).

${ }^{6}$ Biologist, PhD in Theory and Research of Behavior, Professor and researcher of the Graduate Program in Professional and Technological Education (PROFEPT) of the Institute of Basic, Technical and Technological Education of Amapá (IFAP).
}

RC: 52782

Available in: https://www.nucleodoconhecimento.com.br/health/serious-malaria 
Amapá. An epidemiological study, descriptive of retrospective character, was carried out. Data were obtained by consulting data bank for the year 2016. Severe malaria was considered in 47 cases. There were predominant male patients with $63.8 \%$ and the age group up to 5 years with $59.6 \%$ of the cases. As to the species, the most frequent infections were $\mathrm{P}$. vivax with $72 \%$ in relation to $\mathrm{P}$. falciparum with $28 \%$ of cases. The months with the greatest number of hospitalizations were September and November, both with $17 \%$. The main clinical manifestations were: fever, pallor and cough. The conditions that indicated gravity that most occurred: vomiting $87 \%$, jaundice $23 \%$, dyspnoea and age $<1$ year both with $21 \%$. Haematological examinations showed that $91 \%$ of the patients had red blood cells below the reference values and $100 \%$ of the cases had low hemoglobin and hematocrit; thrombocytopenia was observed in $72 \%$ of the cases. Altered results of biochemical dosages of major clinical importance were: urea, transaminases, glycyme and Creactive protein. The identification of epidemiological, clinical and laboratory data of severe malaria contributes to the early diagnosis and appropriate treatment of the disease.

Keywords: Severe malaria, Plasmodium vivax, epidemiology, Amazon Region.

\section{INTRODUCTION}

Malaria is an important public health problem of great interest worldwide. It is an infectious disease caused by protozoa of the genus Plasmodium transmitted by the bite of the female mosquito of the infected Anopheles genus. The main species associated with human malaria are: Plasmodium falciparum, P. vivax, P.malarie and $P$. ovale. Recently, some cases of malaria have been recorded from infections with P. knowlesi and P. cynomolgi, known species that cause malaria in apes (TA et al., 2014; RAMASSAMI, 2014). The most common and proven to be found in Brazil are: P.vivax, P. falciparum and $P$. malarie, since $P$. ovale is more common in regions of Africa (BRASIL, 2009).

RC: 52782

Available in: https://www.nucleodoconhecimento.com.br/health/serious-malaria 
The development of vectors that transmit malaria is very viable in the legal Amazon. The state of Amapá is a state in the northern region, part of the Legal Amazon and one of the states with an environment more conducive to the breeding of the vector and the transmission of malaria. In relation to Brazil, the State of Amapá is among the areas of medium and high risk of contamination (SANTOS; SANTOS, 2011).

The occurrence of malaria cases is related to several factors, including the extractive activities of natural resources, capable of enhancing the transmission of the disease. In this sense, Amapá presents itself as a region that has its economy and survival in the use of natural resources (MACIEL; OLIVEIRA, 2014). In view of the favorable environment and the needs of the population to use natural resources, malaria infection is high in Amapá, and the cases with the highest incidence are those caused by P. vivax, (90\% of cases) (SANTOS; SANTOS, 2011).

Evidence shows that the clinical spectrum of malaria is influenced by the intensity of transmission, the species of parasite and the patient's immune status. Thus, the clinical presentation of malaria appears to differ between children and adults (WASSMER et al., 2015).

\section{AIM}

Identify the epidemiological, clinical and laboratory profile of severe malaria in newborns and adolescents treated in 2016 at a referral hospital in the state of Amapá, Brazil.

\section{METHOD}

This is a retrospective descriptive epidemiological study, developed at the Children's and Adolescents Hospital (HCA) located in the city of Macapá in the State of Amapá, northern Brazil. The data for this research was obtained by consulting the database of the Medical Archive Service (SAME) of HCA. In order to record the information collected, the following topics were removed from the database: demographic

RC: 52782

Available in: https://www.nucleodoconhecimento.com.br/health/serious-malaria 
variables (gender, age, origin ...), clinical variables: number of hospitalizations, length of stay, infectious species ( $P$. vivax, $P$. falciparum, $P$. malaria), clinical manifestations (fever, myalgia, chills, oliguria, jaundice, hyperpyrexia (greater than $41^{\circ} \mathrm{C}$ ), convulsions, etc.) and results of laboratory tests (blood count, hemoscopy (thick drop) and biochemical measurements (urea, creatinine, aspartate aminotransferase (AST) and alanine aminotransferase (ALT), PCR (C-reactive protein) and glycemia).

Children and adolescents of both sexes (aged 29 days from birth to 15 years old) attended from January 1 to December 31,2016 , with laboratory confirmation of malaria (plasmodium research with positive results) were included) and who presented clinical and laboratory manifestations of severe malaria as described in the 2010 Practical Guide to Malaria in 2010, which has the conditions that indicate the severity of the disease and the need for hospitalization: immunosuppressed patients, patients with any of the signs of danger for severe malaria: (hyperpyrexia greater than $41^{\circ} \mathrm{C}$, convulsions, hyperparasitemia $\left(>200.000 / \mathrm{mm}^{3}\right)$, repeated vomiting, oliguria, dyspnea, severe anemia, jaundice, bleeding and arterial hypotension.

The research project was submitted and approved by the Ethics and Research Committee of Faculdade Estácio de Macapá, according to the ethical standards established in the Resolution of the National Health Council No. 466 of December 12, 2012, which deals with research involving human beings (BRASIL, 2013).

\section{RESULTS AND DISCUSSION}

The Amazon, a region where the state of Amapá is located, contributes to the formation of the epidemiological link for the transmission of malaria due to its geographical, climatic and socio-cultural aspects. Thus, knowledge of the dynamics of the disease, from the perspective of the peculiarity of each endemic region and the age range of population development, is of great importance. (BRASIL, 2016).

Initially, the epidemiological aspects of the patients under study were characterized, in terms of gender, age group, origin and infectious species. Thus, there was a

RC: 52782

Available in: https://www.nucleodoconhecimento.com.br/health/serious-malaria 
predominance of male patients who accounted for $63.8 \%(n=30)$ of the cases, while only $36.2 \%(n=17)$ were female (Figure 1$)$.

Figure 1 Percentage of severe malaria cases in 2016 in the state of Amapá, by gender.

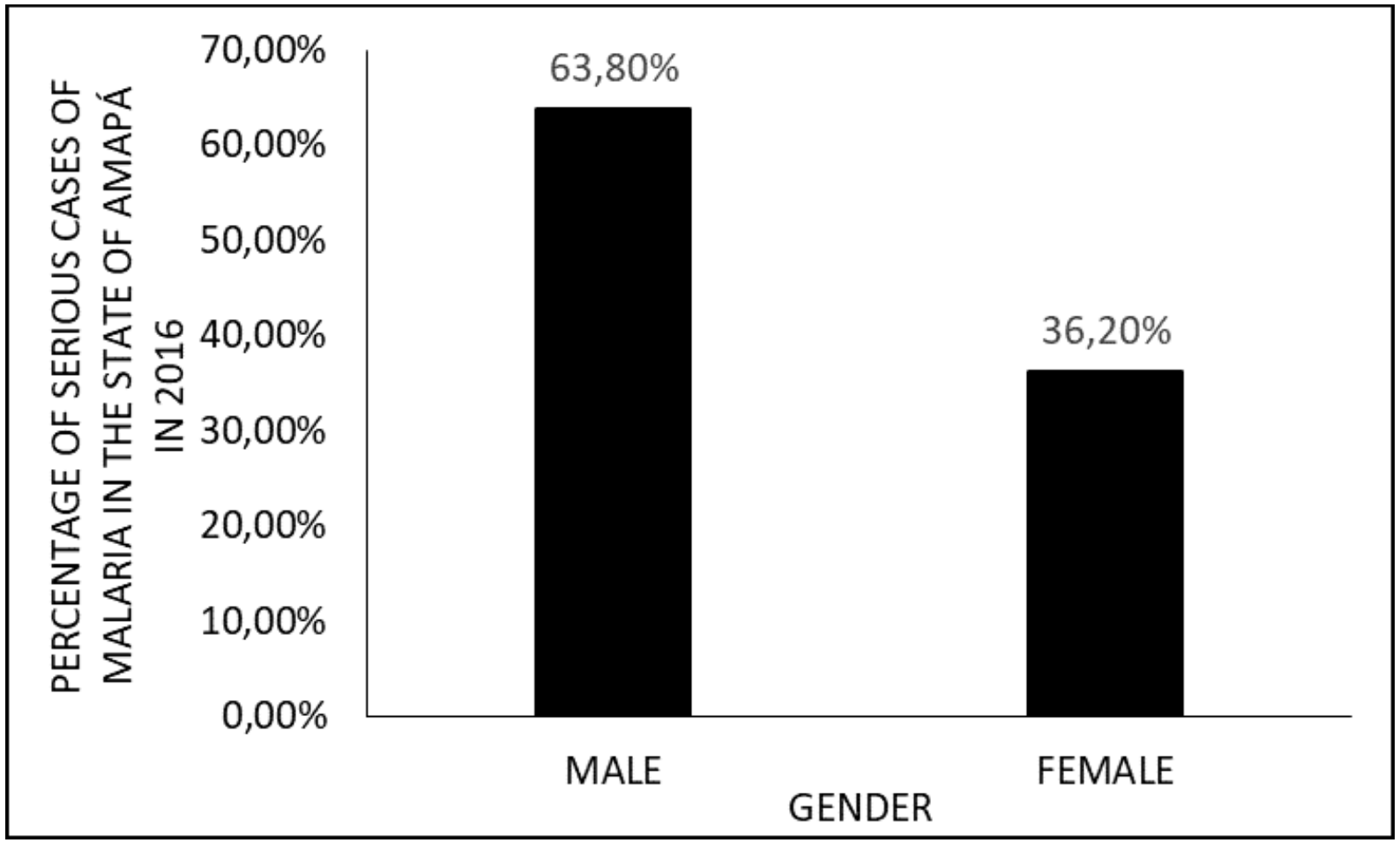

For Monteiro, Ribeiro and Fernandes (2013), men and women are at risk of contracting malaria. Men tend to be less careful about their health than women. Work in areas prone to the presence of vectors is also usually occupied by men (ALMEIDA et al., 2020).

More than half $28(59.6 \%)$ of the cases occurred in patients who belonged to the age group up to 5 years; followed by 6 to 10 years, with $29.8 \%(n=14)$ of the cases. Only $10.6 \%(n=5)$ of the cases occurred in patients aged 11 to 15 years (Figure 2$)$.

RC: 52782

Available in: https://www.nucleodoconhecimento.com.br/health/serious-malaria 
Figure 2 Percentage of cases of severe malaria in 2016 in the state of Amapá, by age group.

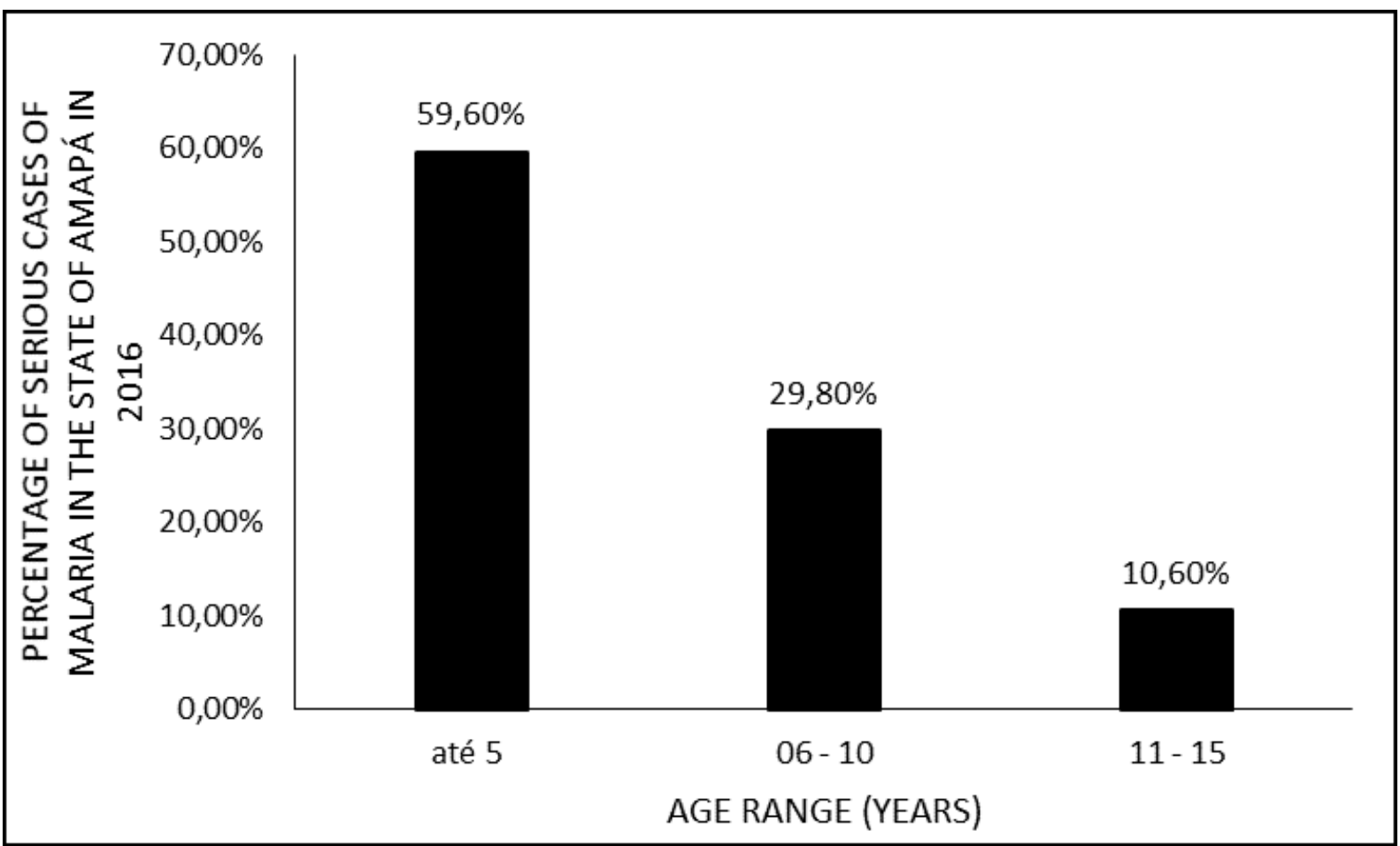

Regarding the age group up to 5 years, in which the numbers of cases were higher, it may be related to the child's susceptibility to acquire diseases, also because they are part of the risk group and the fact that in this study the primary infection prevails. 94\% of the cases, which is a factor that contributes to severity since the individual does not have any specific immunity against plasmodium (VENTURA et al., 1999; GOMES et al., 2011; RIBEIRO, 2012).

As for the infectious species, in this study there was no record in the medical records of the presence of $P$. malaria or mixed malaria, with Plasmodium vivax infections standing out more frequently with $72 \%(n=34)$ in relation to $P$. falciparum that involved $28 \%(n=13)$ of the registered cases (Figure 3$)$.

RC: 52782

Available in: https://www.nucleodoconhecimento.com.br/health/serious-malaria 
Figure 3 Percentage of severe malaria cases in 2016 in the state of Amapá, by age group.

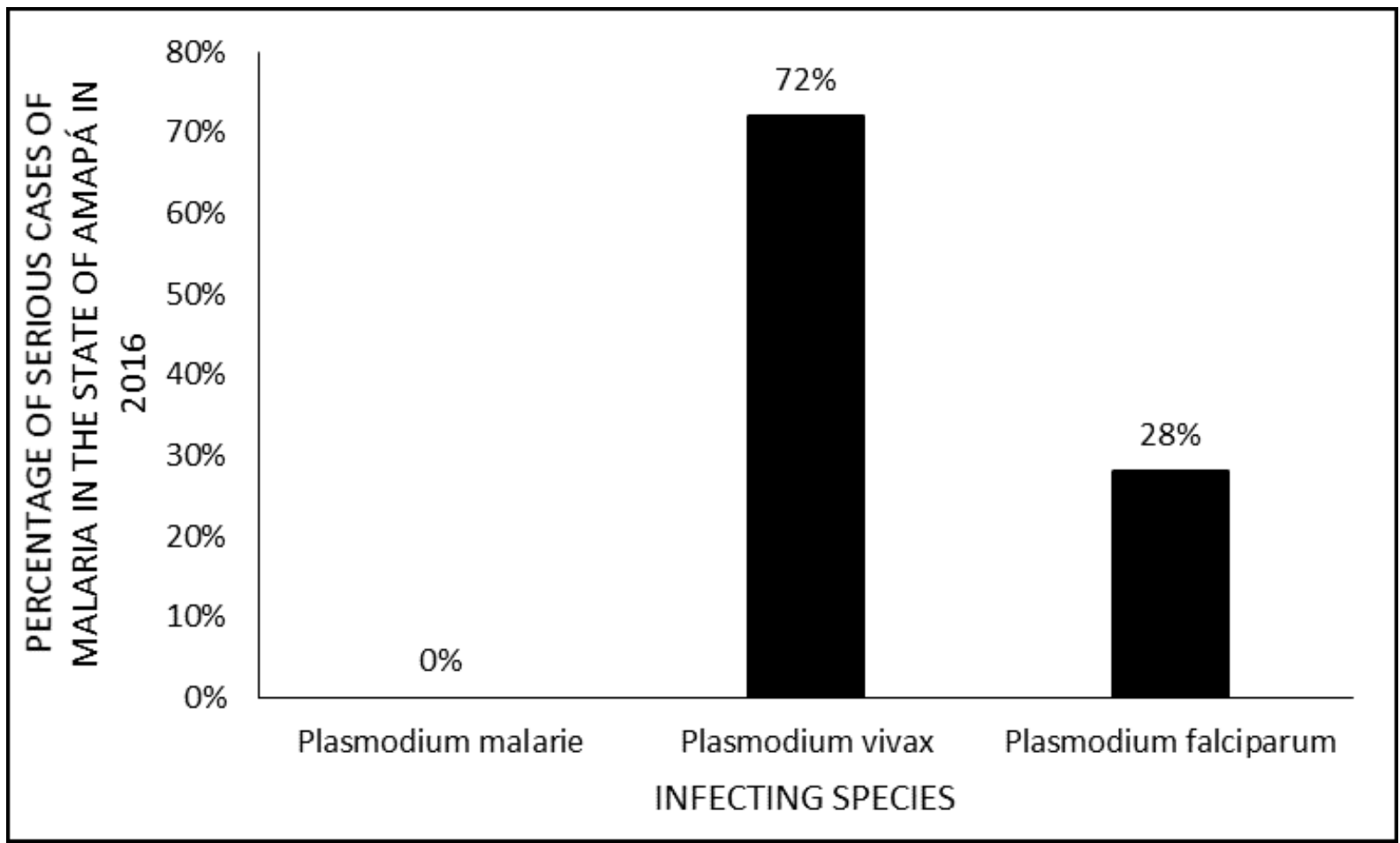

This finding corroborates that found by Santos and Santos (2011), who in their study show a higher incidence of infection by $P$. vivax in the state of Amapá. On the other hand, when analyzing the severity aspect, this amount of infection by $P$. vivax is not so common, since most surveys present severe malaria related to $P$. falciparum (KIRCHGATTER; PORTILLO, 2005; GOMES, 2011; MIOTO; GALHARDI; AMARANTE, 2012; PARISE, 2009).

The origin of these patients, as shown in Table 1, shows that among the municipalities in Amapá, Macapá stood out with 29 cases, 79\% $(n=23)$ P. vivax and $21 \%$ (6) P. falciparum. Given that it can be attributed to the fact that the work was carried out in the Capital.

Table 1 Distribution of patients admitted to the HCA with severe malaria according to the municipality of residence and infectious species in 2016, Macapá-AP.

RC: 52782

Available in: https://www.nucleodoconhecimento.com.br/health/serious-malaria 


\begin{tabular}{|c|c|c|c|c|c|c|}
\hline \multirow{2}{*}{ Município de procedência/ Espécie infectante } & \multicolumn{2}{|c|}{ P. vivax } & \multicolumn{2}{|c|}{ P. falciparum } & \multicolumn{2}{|c|}{ Total } \\
\hline & $\mathrm{N}$ & $\%$ & $\mathrm{~N}$ & $\%$ & $\mathrm{~N}$ & $\%$ \\
\hline Macapá & 23 & 79 & 6 & 21 & 29 & 100 \\
\hline Mazagão & 2 & 67 & 1 & 33 & 3 & 100 \\
\hline Ferreira Gomes & 1 & 25 & 3 & 75 & 4 & 100 \\
\hline Porto Grande & 1 & 33 & 2 & 67 & 3 & 100 \\
\hline Tartarugalzinho & 4 & 100 & 0 & 0 & 4 & 100 \\
\hline Oiapoque & 1 & 100 & 0 & 0 & 1 & 100 \\
\hline Outros Estados (PA) & 2 & 67 & 1 & 33 & 3 & 100 \\
\hline Total & 34 & 72 & 13 & 28 & 47 & 100 \\
\hline
\end{tabular}

Fonte: Same/HCA

A similar occurrence was observed in a research, carried out in a reference hospital in Belém do Pará, in which the other municipalities alone were also not very representative (MONTEIRO; RIBEIRO; FERNANDES, 2013). Thus, although the entire state of Amapá is an endemic area, it is assumed that the population is being assisted, with proper diagnosis and treatment in less complex units in the municipalities of residence.

Still on table 1, the species distribution by municipality, differs from the others presented, Ferreira Gomes with 75\% (3/4) and Porto Grande 67\% (2/3) of infection by $P$. falciparum, is where it is verified a slight predominance of cases of infection by this species, a finding common in several studies where the cases of severe malaria caused by $P$. falciparum (KIRCHGATTER; PORTILLO, 2005; PARISE, 2009; GOMES, 2011; MIOTO; GALHARDI; AMARANTE, 2012).

The municipality in Amapa with the lowest number of cases was Oiapoque, with only 1 caused by $P$. vivax. The remaining 3 cases were attended to patients from another state, in this case Pará from the cities of Breves and Afuá, with $67 \%(\mathrm{n}=2) P$. vivax and $33 \%$ (1) P. falciparum.

The months with the highest frequency of hospitalizations for severe malaria were the months of September and November with $8(17 \%)$ of hospitalizations each. While the months of March, April and May had the lowest number, only $2 \%$ (1) of

$\mathrm{RC}: 52782$

Available in: https://www.nucleodoconhecimento.com.br/health/serious-malaria 
hospitalization, as shown in (figure 4). Malaria seasonality is variable in each state of the Amazon region, but in general, there is a peak of cases in the transition period between the dry and wet seasons (BRASIL, 2016).

Figure 4 Percentage of cases of severe malaria in 2016 in the state of Amapá, by months of the year.

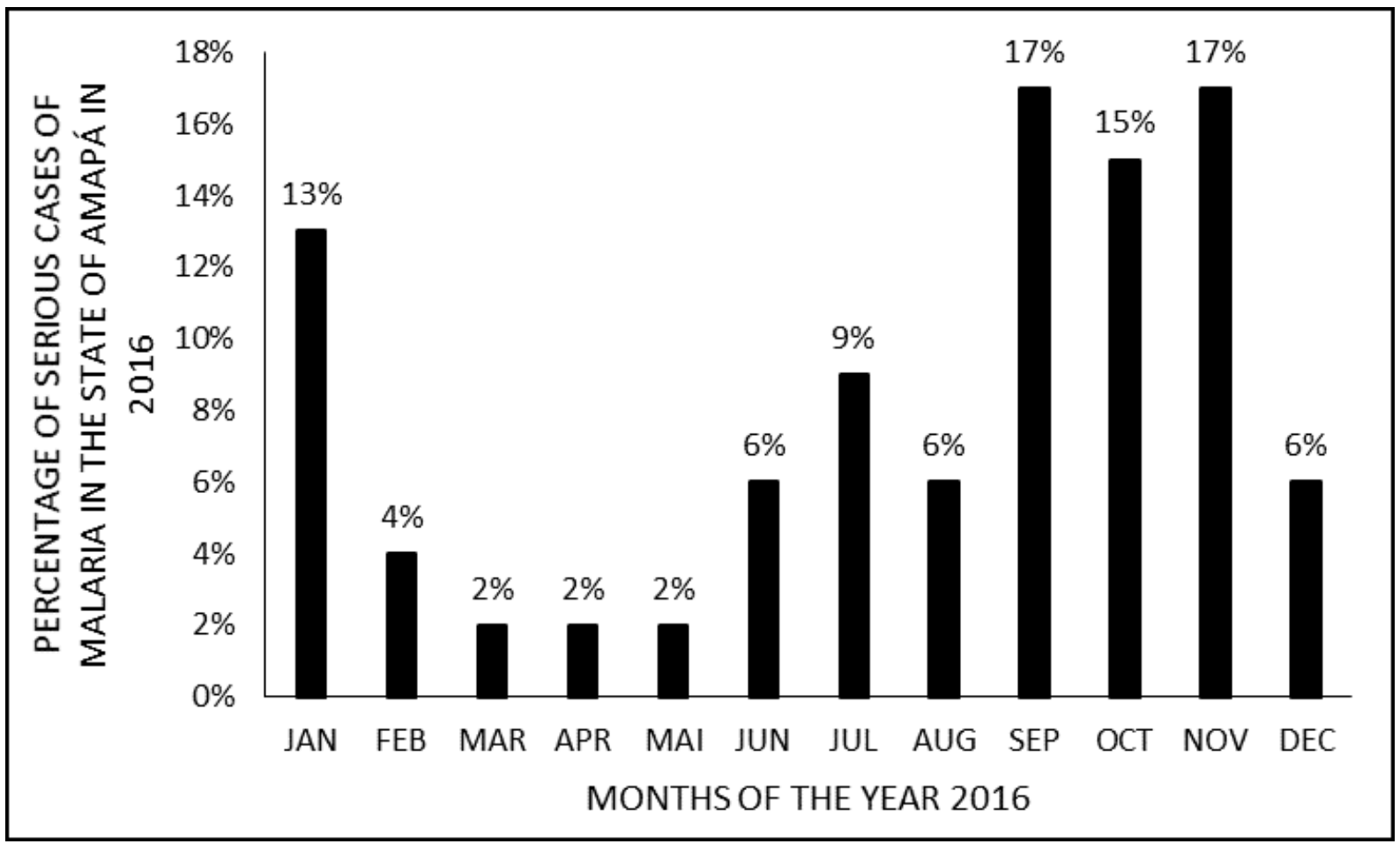

The main vector of malaria in Brazil, Anopheles darlingi, reproduces in large quantities in low-flow, deep and shaded waters, and its reproduction decreases in rainy periods (MONTEIRO; RIBEIRO; FERNANDES, 2013). In the state of Amapá, the month of September presents a low rate of rain and November the beginning of the rainy season, a fact that may justify the greater number of hospitalizations for severe malaria in this study. Certainly, in addition to climate change, other factors, such as socioenvironmental and mainly, variations in the quality and quantity of control actions may be related to the greater or lesser incidence of the disease (BRASIL, 2016).

RC: 52782

Available in: https://www.nucleodoconhecimento.com.br/health/serious-malaria 
As for the length of hospital stay, several factors can influence the permanence of these patients in the hospital environment, the (figure 5) shows that the majority of patients remained hospitalized for up to 5 days. The two patients infected with $P$. vivax who remained for 16 to 20 days both had dehydration, anemia and thrombocytopenia, one of whom had more leukopenia, jaundice, choluria and very high transaminase test results.

Figure 5 Percentage of cases of severe malaria in 2016 in the state of Amapá, by days of hospitalization.

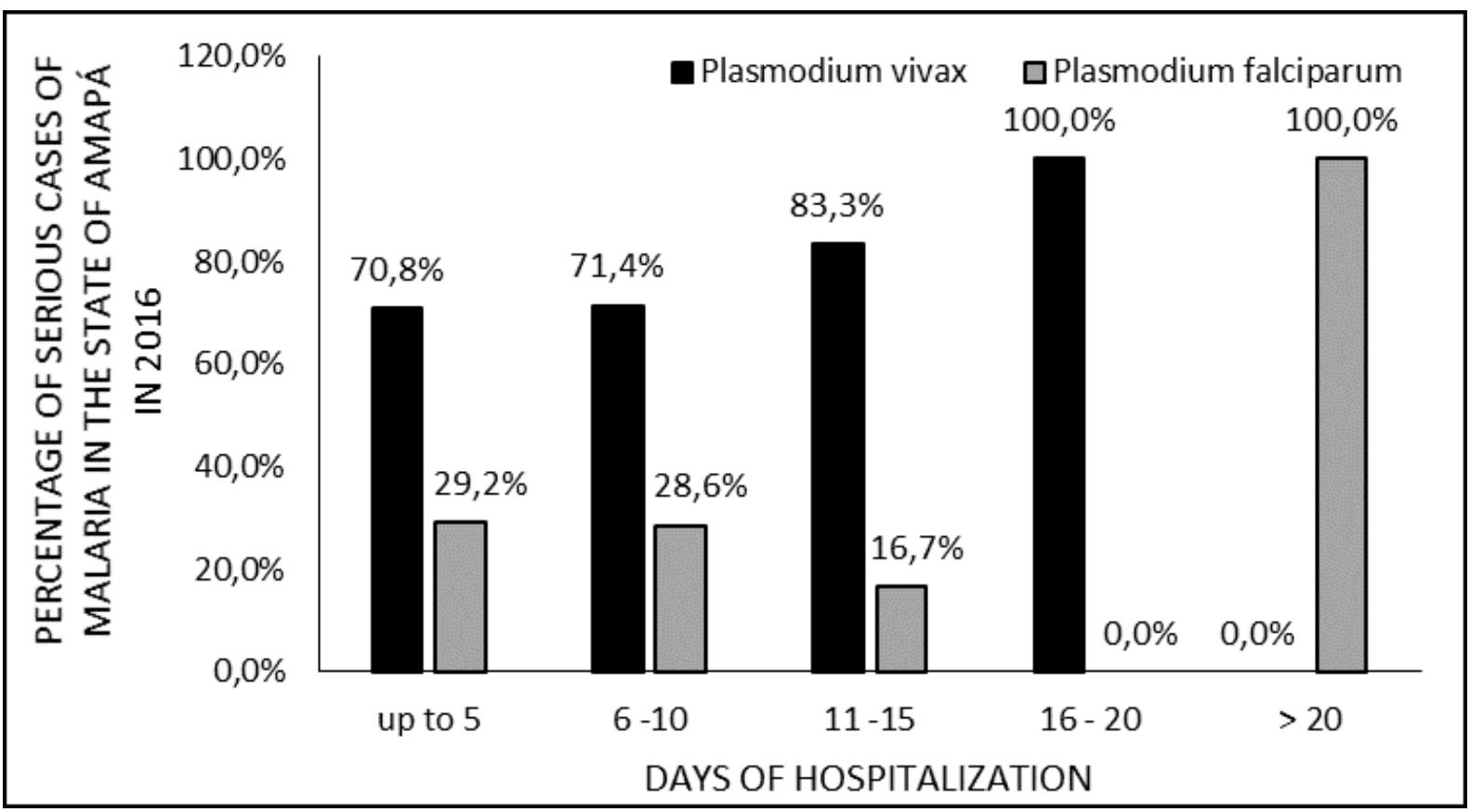

The patient with $P$. falciparum infection, more than 20 days old, was one year old, had a high parasitemia of $192.000 \mathrm{f} / \mathrm{mm}^{3}$, hepatosplenomeglia, thrombocytopenia, severe anemia and underwent red blood cell transfusion. It has been well documented that intense anemia, a clinical manifestation present in severe malaria and is an important factor that contributes to morbidity, length of stay and even mortality, occurring in infections by $P$. falciparum and quite often also by $P$.vivax (PRICE et al., 2007; NAING et al., 2014).

RC: 52782

Available in: https://www.nucleodoconhecimento.com.br/health/serious-malaria 
According to the information analyzed, the time elapsed until the diagnosis of malaria, which is also a decisive factor for cure or progression to severity, was: up to 3 days $40 \%$, from 4 to 5 days $38 \%$ of patients, from 6 to $1017 \%$ days and from 11 to 15 days $4 \%$ of cases. All patients were discharged only after improvement of the clinical and laboratory conditions, with referral to outpatient control with pediatric infection, there was no record of death in the studied period.

The most common clinical manifestations found were: fever, pallor, cough, bloating, abdominal pain, dehydration, headache, chills and diarrhea (table 2). Fever was present in $100 \%$ of cases, which for Ramos (2006), is the main reason that leads most patients to seek medical care and to carry out complementary diagnostic tests.

Paleness, in turn, occurred in $96 \%$ of patients, as it is a very common clinical manifestation in cases of malaria, a result similar to that of Ventura et al. (1999) who in their study also carried out with children and adolescents (85\%) showed pallor.Shivering and headache both occurred in only 30\% (14/47) of the patients.

These are symptoms that most often accompany fever, forming the classic malarial triad (BRASIL, 2009). Perhaps it was not observed either due to the lack of registration at the time of the anamnesis, or because it is a study with serious cases where the manifestations may present themselves in an atypical way.

Abdominal pain was present in (32\%) and diarrhea (23\%) of patients, according to Ramos (2006), may have malaria origin, but in endemic areas, socioeconomic conditions are generally precarious, with inadequate sanitation which can lead to to infections by intestinal parasites by eating contaminated food and water, which can add up and intensify these symptoms at the time of infection.

Patients who had ascites, choluria, drowsiness, and diarrhea were infected with $P$. vivax. Those who presented splenomegaly, anorexia and tachycardia had infection with $P$. falciparum, the other manifestations in table 2 occurred both in infections by P. falciparum and $P$. vivax.

RC: 52782

Available in: https://www.nucleodoconhecimento.com.br/health/serious-malaria 
Table 2 Distribution of clinical manifestations present in HCA patients with severe malaria in 2016. Macapá, Amapá.

\begin{tabular}{lcc}
\hline & \multirow{2}{*}{ Manifestações Clínicas } & \multicolumn{2}{c}{ Frequencia $(\mathrm{N}=47)$} \\
\cline { 2 - 3 } & $\mathrm{N}$ & $\%$ \\
\hline Febre & 47 & 100 \\
Palidez & 45 & 96 \\
Tosse & 20 & 43 \\
Distensão Abdominal & 20 & 43 \\
Dor Abdominal & 15 & 32 \\
Desidratação & 14 & 30 \\
Calafrio & 14 & 30 \\
Cefaléia & 14 & 30 \\
Diarreia & 11 & 23 \\
Edema & 6 & 13 \\
Náuseas & 6 & 13 \\
Hepatomegalia & 5 & 11 \\
Hematúria & 4 & 9 \\
Colúria & 3 & 6 \\
Ascite & 2 & 4 \\
Sonolência & 2 & 4 \\
Esplenomegalia & 1 & 2 \\
Anorexia & 1 & 2 \\
Taquicardia & 1 & 2 \\
\hline
\end{tabular}

Fonte: Same/HCA

Recently, the occurrence of severe cases of malaria by $P$. vivax is emphasized (SIROMA, 2016; WASSMER et al., 2015; LACERDA et al., 2012). Many of the most serious clinical manifestations that occur in $P$. falciparum malaria have also been described in patients with P. vivax (MONTEIRO; RIBEIRO; FERNANDES, 2013; SALAS et al., 2013). A fact evidenced in the present study (Table 3), patients diagnosed with malaria by $P$. vivax presented vomiting, jaundice, dyspnea, severe anemia, oliguria, convulsion and hemorrhage. These are conditions that indicate severity and need for hospitalization (BRASIL, 2010).

The most frequent severity condition was vomiting, $100 \%$ in patients infected with $P$. Falciparum and $68 \%$ in those infected with $P$. vivax, a situation that in the medical records justified most of the hospitalizations, because the children did not tolerate

RC: 52782

Available in: https://www.nucleodoconhecimento.com.br/health/serious-malaria 
oral medication, requiring so from intravenous medication. According to Ramos (2006), vomiting can hinder the correct treatment, leading to not taking the drugs or inadequate absorption of them, in addition to leading to dehydration, as seen in (table 2) where $30 \%$ (14/47) presented dehydration.

Respiratory signs and symptoms such as cough (table 2) and dyspnea (table 3) were recorded in both patients infected with $P$. falciparum and $P$. vivax, but it cannot be said that they were caused exclusively by malaria, as the results were not analyzed gasometry, spirometry and radiographic examinations of the majority, only the latter in a patient who was diagnosed with malaria associated with pneumonia.

Respiratory signs and symptoms and pulmonary complications have been the subject of study. Val et al. (2017) showed that respiratory complications were significantly associated with cases of patients with severe malaria who died. Carvalho et al. (2010) reported that P. vivax has the ability to adhere to human lung endothelial cells. For Salas et al. (2013) pathophysiological processes could be shared by these two species, such as sequestration of infected erythrocytes from the peripheral circulation into vital organs (lung, brain and kidneys) and cytoadherence to the capillary endothelial wall of these organs.

According to Carvalho et al. (2010), these observations lead to a modification of the current paradigms of the pathogenesis of malaria and open the way to investigate the pathophysiology of $P$. vivax infections, since as erythrocytes infected with $P$. vivax do not have button structures (surface changes) and because all forms of the parasite can be observed in the patients' peripheral blood, it has become dogma that $P$. vivax is not capable of kidnapping and, therefore, neither of cytoadherence (LOPES et al., 2014).

Another serious condition found was intense anemia, in (5/47) cases, 4 infections by $P$. vivax and 1 by $P$. falciparum. Severe anemia, which is defined as hematocrit less than $15 \%$ and hemoglobin less than $5 \mathrm{~g} / \mathrm{dL}$, is usually present in severe malaria due to intense destruction and sequestration of red blood cells, alteration in

RC: 52782

Available in: https://www.nucleodoconhecimento.com.br/health/serious-malaria 
erythropoiesis, and eventual hemorrhages (BRASIL, 2010; GOMES et al. , 2011; SIROMA, 2016).

In the present study, there were records of nine patients who underwent blood transfusion, required red blood cell concentrate, 2 of 9 also needing platelets, of these 9 patients eight were infected with $P$. vivax, and only one with $P$. falciparum. The bleeding patient was one of the patients who underwent blood transfusion of red blood cells and platelets.

Similar complications related to severe mlaria involving $P$. vivax have been described in other studies as severe anemia, liver dysfunction, jaundice, thrombocytopenia with or without bleeding (WASSMER et al., 2015; LACERDA et al., 2012; SALAS et al., 2013 ;)

Regarding the age $<1$ year in which there were (10/47) patients (table 3 ), according to Gomes et al (2011), the severity of malaria depends on the relationship between host (vulnerability and immune status) and Plasmodium spp (species disease and parasitic density). And small children, the primoinfected and pregnant women are hosts that are more vulnerable to severe forms of the disease, as has been mentioned in the course of the work.

RC: 52782

Available in: https://www.nucleodoconhecimento.com.br/health/serious-malaria 
Table 3 Distribution of conditions that indicate severity and need for hospitalization according to the infectious species in patients hospitalized with severe malaria in 2016, Macapá - AP.

\begin{tabular}{lccccccc}
\hline \multirow{2}{*}{$\begin{array}{c}\text { Condições que indicam gravidade e } \\
\text { necessidade de internação }\end{array}$} & \multicolumn{3}{c}{ Espécie Infectante } \\
\cline { 2 - 8 } & $\begin{array}{c}\text { P. falciparun } \\
\text { (N=13) }\end{array}$ & $\begin{array}{c}P \text {. Vivax } \\
(\mathrm{N}=34)\end{array}$ & \multicolumn{3}{c}{ Total } \\
\cline { 2 - 8 } & $\mathrm{N}$ & $\mathbf{N}=47)$ & $\mathrm{N}$ & $\%$ & $\mathrm{~N}$ & $\%$ \\
\hline Vômitos repetidos & 13 & 32 & 28 & 68 & 41 & 100 \\
Icterícia & 3 & 27 & 8 & 73 & 11 & 100 \\
Dispneia & 3 & 30 & 7 & 70 & 10 & 100 \\
Idade $<1$ ano & 0 & 0 & 10 & 100 & 10 & 100 \\
Anemia Intensa $(\mathrm{Hb}<5 \mathrm{~g} / \mathrm{dL})$ & 1 & 20 & 4 & 80 & 5 & 100 \\
Oligúria & 1 & 33 & 2 & 67 & 3 & 100 \\
Convulsão & 0 & 0 & 2 & 100 & 2 & 100 \\
Hemorragias & 0 & 0 & 1 & 100 & 1 & 100 \\
\hline
\end{tabular}

The highest level of parasitemia was recorded in infection by $P$. falciparum with $192,000 \mathrm{f} / \mathrm{mm}^{3}$. Among the studied patients, P. vivax showed a maximum level of $30,000 \mathrm{v} / \mathrm{mm}^{3}$. The main pathogenic events attributed to $P$. falciprum are well described in the literature, such as the ability to infect erythrocytes at all stages, thus presenting high parasitemias, the phenomenon of sequestration of infected erythrocytes from the peripheral blood circulation and the ability to adhere to the capillary endothelium. internal organs, so that few mature forms are seen in peripheral blood samples during infection (KIRCHGATTER; PORTILLO, 2005; CARVALHO et al., 2010).

As for the laboratory profile (table 4), hematological tests showed that $91 \%(43 / 47)$ of the patients had red blood cells below the reference values and $100 \%$ of the cases had low hemoglobin and hematocrit. They presented thrombocytopenia (reduced number of platelets) $n=34$ patients, among them, $71 \%(n=24)$ had $P$. vivax malaria and $29 \%(\mathrm{n}=10) P$. falciparum. This hematological evidence is very frequent, especially in cases of severe malaria (RAMOS, 2006; LACERDA et al., 2012; SIROMA, 2016).

RC: 52782

Available in: https://www.nucleodoconhecimento.com.br/health/serious-malaria 
Table 4 Distribution of the results of laboratory tests of patients treated for severe malaria in 2016, Macapá-AP.

\begin{tabular}{|c|c|c|c|c|c|c|c|c|c|c|c|c|c|c|c|}
\hline \multirow{3}{*}{ Exames laboratoriais } & \multicolumn{15}{|c|}{ Resultados $(\mathrm{N}=47)$} \\
\hline & \multicolumn{5}{|c|}{ Baixo } & \multicolumn{5}{|c|}{ Normal } & \multicolumn{5}{|c|}{ Elevado } \\
\hline & $\mathrm{N}$ & $\%$ & \multicolumn{3}{|c|}{ Média/DP } & $\mathrm{N}$ & $\%$ & \multicolumn{3}{|c|}{ Média/DP } & $\mathrm{N}$ & $\%$ & \multicolumn{3}{|c|}{ Média/DP } \\
\hline Hemácias (milhões $/ \mathrm{mm}^{3}$ ) & 43 & 91 & 3,23 & \pm & 0,79 & 4 & 9 & 4,38 & \pm & 0,06 & 0 & 0 & - & \pm & - \\
\hline Hemoglobina ( $\mathrm{g} / \mathrm{dL}$ ) & 47 & 100 & 8,93 & \pm & 2,29 & $\mathbf{0}$ & 0 & - & \pm & - & $\mathbf{0}$ & 0 & - & \pm & - \\
\hline Hematócrito (\%) & 47 & 100 & 26,71 & \pm & 6,63 & 0 & 0 & - & \pm & - & 0 & 0 & - & \pm & - \\
\hline Leucócitos $\left(\mathrm{mil} / \mathrm{mm}^{2}\right)$ & 3 & 6 & 2.863 & \pm & 824 & 40 & 85 & 6.504 & \pm & 1.628 & 4 & 9 & 15.500 & \pm & 7.154 \\
\hline Plaquetograma $\left(\mathrm{mil} / \mathrm{mm}^{2}\right)$ & 34 & 72 & 48.529 & \pm & 23.384 & 13 & 28 & 140.923 & \pm & 31.690 & 0 & 0 & - & \pm & - \\
\hline Criatinina (mg/dL) & 19 & 79 & 0,38 & \pm & 0,12 & 5 & 21 & 0,92 & \pm & 0,27 & 0 & $\mathbf{0}$ & - & \pm & - \\
\hline Uréia (mg/dL) & 1 & 4 & 9,00 & \pm & - & 18 & 78 & 24,17 & \pm & 8,51 & 4 & 17 & 60,25 & \pm & 17,56 \\
\hline AST (U/L) & 0 & 0 & - & \pm & - & 9 & 28 & 28,42 & \pm & 13,95 & 23 & 72 & 127,74 & \pm & 185,01 \\
\hline ALT (U/L) & 0 & 0 & - & \pm & - & 18 & 56 & 20,94 & \pm & 7,23 & 14 & & 137,29 & \pm & 140,01 \\
\hline Glicemia (mg/dL) & 1 & 14 & 31,00 & \pm & - & 2 & 29 & 102,50 & \pm & 0,71 & & 57 & 130,25 & \pm & 9,03 \\
\hline PCR (mg/dL) & 0 & 0 & - & \pm & - & 1 & 3 & 0,20 & \pm & - & 36 & 97 & 6,29 & \pm & 3,31 \\
\hline \multicolumn{16}{|c|}{ 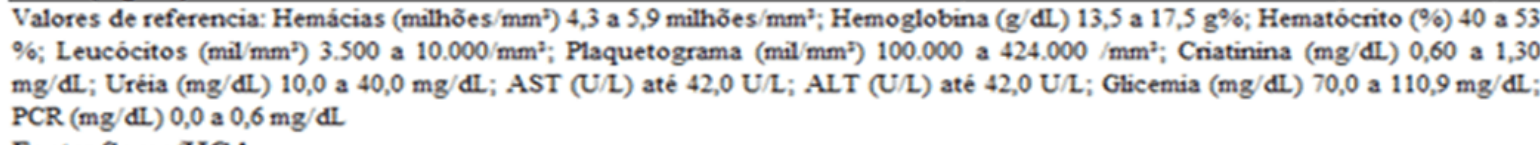 } \\
\hline $\mathrm{me} / \mathrm{HCA}$ & & & & & & & & & & & & & & & \\
\hline
\end{tabular}

Regarding the dosages of urea and creatinine that assess renal functions, only urea stood out with high values, which may indicate kidney impairment. Of the $(23 / 47)$ patients who underwent this examination, only $17 \%(n=4)$ had high values, all of whom were affected by $P$. vivax.

As for the tests that are part of the liver evaluation, aspartate aminotransferase (AST) and Alanine aminotransferase (ALT) both were performed in 68\% (32/47) of the patients, and of the 32, they presented high values of (AST) $72 \%(n=23)$, among which $22 \%(n=7)$ were $P$. falciparum and $50 \%(n=16)$ were $P$. vivax. And $44 \%$ $(14 / 32)$ had high $(A L T)$ results, with $19 \%(n=6)$ being $P$. falciparum and $25 \%(n=8)$ were $P$. vivax.

The elevation of transaminases (table 4) as well as the presence of jaundice (table 3) show hepatic impairment, as the asexual cycle of the plasmodium called preerythrocytic or tissue schizogony, occurs in the liver breaking up the hepatocytes, eventually leading to an inflammatory process in this organ (RAMOS, 2006; BRASIL, 2009).

RC: 52782

Available in: https://www.nucleodoconhecimento.com.br/health/serious-malaria 
As for the glycemia test, it was detected that only $7 / 47$ (15\%) were performed, where of that total $(\mathrm{n}=1)$ affected by $P$. Vivax, he presented hypoglycemia, which is a common occurrence in severe malaria, it usually occurs in association with other complications (GOMES, 2011; RIBEIRO, 2012).

It is noteworthy that $40 / 47(85 \%)$ of the patients did not undergo a glycemic test, according to the Practical Guide to Malaria Treatment in Brazil, blood glucose is one of the laboratory determinations, as well as blood count, determination of parasitemia, arterial blood gases and renal and liver function parameters (BRASIL, 2010). The lack of documentation of patient test results makes it difficult to observe the dynamics of the disease, that is, to trace the clinical profile of the patients.

The measurement of C-reactive protein (CRP) was performed in 79\% (37/47) of the patients, and of these $(n=37), 97 \%(n=36)$ had high levels of C-reactive protein. The patients with high levels were $24 \%(n=9) P$. falciparum and $73 \%(n=27) P$. vivax.

C-reactive protein is synthesized in the liver and is a non-specific marker that rises in acute phase responses when tissue injury is stimulated, including infections by various microorganisms (COLLARES, 2006). Evidence has already been identified about the increase in plasma levels of C-reactive protein and the progression of malaria severity (LACERDA et al., 2012).

$P$. vivax and $P$. falciparum are the main species that cause human malaria, as they are responsible for most cases of morbidity and mortality on the globe. While $P$. falciparum is considered the most lethal species, $P$. vivax is considered the most widely distributed on the globe (BATTLE et al., 2014).

\section{CONCLUSION}

This study showed the epidemiological, clinical and laboratory profile of severe malaria in children and adolescents, taking into account not only the infections

$\mathrm{RC}: 52782$

Available in: https://www.nucleodoconhecimento.com.br/health/serious-malaria 
caused by Plasmodium falciparum, which is commonly recommended as the main cause of severe malaria, but complications related to Plasmodium vivax have been carefully described.

It was possible to observe within this study both $P$. falciparum and $P$. vivax associated with severe malaria. A high proportion of $P$. vivax infection was found, which was responsible for the only case of hemorrhage, for the only two cases of seizure and for eight blood transfusions. The finding of many hospitalizations due to $P$. vivax infection highlights the severity potential of this species.

However, further studies are needed to clarify the pathophysiological mechanisms that lead to severe $P$. vivax malaria. Since the new malaria scenario shows that Plasmodium vivax has been changing its way of interacting with the human host, it can no longer be considered a benign parasite. The finding of this paradigm shift further increases the challenges in controlling this disease, since $P$. vivax is considered the most prevalent species in the world, this may have an impact on the worsening of the current malaria situation.

Even though the present study does not reflect the population prevalence of Amapá, the data presented here can contribute to guide care demands, favoring better adaptations of specialized services. Because the identification of epidemiological, clinical and laboratory data on severe malaria is a strategy for early diagnosis and adequate treatment, aiming to mitigate the impacts caused by the disease.

\section{REFERENCES}

ALMEIDA, H.K. S. et al. Casos confirmados de malária no Brasil entre os anos de 2011 e 2015. Revista Científica Multidisciplinar Núcleo do Conhecimento. Ano 05, Ed. 04, Vol. 07, pp. 05-16, 2020. ISSN: 2448-0959, Disponível em: $<$ https://www.nucleodoconhecimento.com.br/saude/malaria-no-brasil>, DOI: 10.32749/nucleodoconhecimento.com.br/saude/malaria-no-brasil

RC: 52782

Available in: https://www.nucleodoconhecimento.com.br/health/serious-malaria 
BATTLE, K. E. et al. Geographical variation in Plasmodium vivax relapse. Malaria Journal, 2014, 13:144. https://doi.org/10.1186/1475-2875-13-144.

BOTELHO, C. et al. Manifestações respiratórias na malária por Plamodium falciparum e vivax. Rev. Inst. Med. trop. São Paulo, 1987 29(6):337-345.

BRASIL. Ministério da Saúde. Guia prático de tratamento da malária no Brasil. Brasília: Ministério da Saúde, 2010.

BRASIL. Ministério da Saúde. Secretaria de Vigilância em Saúde. Plano de eliminação de malária no Brasil. Brasília: Ministério da Saúde, 2016.

BRASIL. Ministério da Saúde. Conselho Nacional de Saúde. Resolução № 466, de 12 de dezembro de 2012. Diretrizes e normas regulamentadoras de pesquisas envolvendo seres humanos. Diário Oficial da União, Brasília, DF, 13 jun. 2013. Seção I, p.59-62.

. Ministério da Saúde. Manual de diagnóstico laboratorial da malária. 2 ed. Brasília: Ministério da Saúde, 2009.

CARDOSO, Rosilene Ferreira. Efeito da sazonalidade na curva endêmica da malária por Plasmodium falciparum e vivax no garimpo do Lourenço: uma série temporal histórica na Zona da Amazônia Brasileira. UFRGS. 2014. Disponível em: http://hdl.handle.net/ 10183/114973. Acesso em: 06/11/2017.

CARVALHO, Bruna $O$. et al. On the Cytoadhesion of Plasmodium vivax-Infected Erythrocytes, The Journal of Infectious Diseases, Volume 202, Issue 4, 15 August 2010, Pages 638-647, https://doi.org/10.1086/654815. Acess: 12/09/2017.

COLLARES, Guilherme Birchal; PAULINO, Urquiza Helena Meira. Aplicações clínicas atuais da proteína c reativa. Rev Med Minas Gerais, 2006; 16(4): 227-333. Disponível em: http://rmmg.org/artigo/detalhes/579. Acesso em: 15/11/2017.

$\mathrm{RC}: 52782$

Available in: https://www.nucleodoconhecimento.com.br/health/serious-malaria 
GOMES, Andréia Patricia. et al. Malária grave por Plasmodium falciparum. Rev Ter Intensiva. Viçosa (MG). v 23, n 358 - 369, 2011.

HADDAD, Nagib. Metodologia de estudos em ciências da saúde. São Paulo: Roca; 2004.

KIRCHGATTER, Karin; PORTILO, Hernando A. Del. Aspectos Clínicos e Moleculares da Malária Grave. Anais da Academia Brasileira de Ciências. Rio de Janeiro, v. 77, n 3, 2005.

LACERDA, M. V. et al. Understanding the clinical spectrum of complicated Plasmodium vivax malaria: a systematic review on the contributions of the Brazilian literature. Malaria Journal, 11, 12.2012.

LOPES, Stefanie C. P. et al. Paucity of Plasmodium vivaxMature Schizonts in Peripheral Blood Is Associated With Their Increased Cytoadhesive Potential, The Journal of Infectious Diseases, Volume 209, Issue 9, 1 May 2014, Pages 1403 1407, https://doi.org/10.1093/infdis/jiu018. Acess: 12/09/2017.

MACIEL, Giovana Belem Moreira Lima; OLIVEIRA, Elaine Cristina de. Perfil entomológico e epidemiológico da malária em região garimpeira no norte do Mato Grosso, 2011. Epidemiol. Serv. Saúde, Brasília, v. 23, n. 2, p. 355-360, jun. 2014.

MIOTO, Leide Daiana; GALHARDI, Ligia Carla Faccin; AMARANTE, Marla Karine. Aspectos parasitológicos e imunológicos da malária. Biosaúde, Londrina, v. 14, n. 1, 2012. Disponível: http://www.uel.br/revistas/uel/index.php/biosaude/article/view/ 24324/17894. Acesso em: 07/11/2017.

MONTEIRO, M. R. C. C.; RIBEIRO, M. C.; FERNANDES, S. C. Aspectos clínicos e epidemiológicos da malária em um hospital universitário de Belém, Estado do Pará,

Brasil. Revista Pan-Amazônica de Saúde, v.4, n.2, p.33-43, 2013. Disponível em: <http://dx.doi.org/10.5123/S2176-62232013000200005

RC: 52782

Available in: https://www.nucleodoconhecimento.com.br/health/serious-malaria 
NAING, Cho et al. "Is Plasmodium Vivax Malaria a Severe Malaria?: A Systematic Review and Meta-Analysis." PLoS Neglected Tropical Diseases 8.8 (2014): e3071. PMC. Web. 16 Nov. 2017. Doi: 10.1371/journal.pntd.0003071

PARISE, Éldi Vendrame. Malária grave em Palmas, Estado do Tocantins: relato de caso. Rev. Soc. Bras. Med. Trop. [online]. 2009, vol.42, n.4, pp.463-468. ISSN 0037-8682. http://dx.doi.org/10.1590/S0037-86822009000400021.

PRICE, R. N. et al. Vivax malaria: neglected and not benign. The American Journal of Tropical Medicine and Hygiene, Volume 77, Issue 6_Suppl, Dec 2007, p. 79 87. DOI: https://doi.org/10.4269/ajtmh.2007.77.79

RAMASAMY, Ranjan. Zoonotic malaria-global overview and research and policy needs. Frontiers in public health, v. 2, 2014.

RAMOS, Cristina Bastos Silva Raposo. Malária vivax na pré-amazônia maranhense: aspectos epidemiológicos e características clínicas. 2006. 110 f., il. Dissertação (Mestrado em Ciências Florestais)-Universidade de Brasília, Brasília, 2006.

SALAS, Briegel de Las et al. Adherence to human lung microvascular endothelial cells (HMVEC-L) of Plasmodium vivax isolates from Colombia. Malaria Journal. 2013,12: 347-10.1186/1475-2875-12-347. https://doi.org/10.1186/1475-2875-12-347. Access: $12 / 11 / 2017$.

SANTOS, Rafael Cleison Silva dos; SANTOS, Elinaldo da Conceição dos. Malária: cobaias humanas no Amapá. Estação Científica (UNIFAP). Macapá, v. 1, n. 2, p. 143-150, 2011. Disponível em: https://periodicos.unifap.br/index.php/estacao/article/ download/ 244/cleisonv1n2.pdf. Acesso : 08/10/2016.

SIROMA, Thais Keiko; FERRARI, Eduardo Cal; RIGO, Rosângela Silva. Plasmodium vivax: causa de malária grave. Revista da Sociedade Brasileira de Clínica Médica. $2016 \quad$ jul-set;14(3):166-71. Disponível: http://www.sbcm.org.br/revistas/RBCM/RBCM-2016-03.pdf\#page=47

$\mathrm{RC}: 52782$

Available in: https://www.nucleodoconhecimento.com.br/health/serious-malaria 
TA, Thuy $\mathrm{H}$. et al. First case of a naturally acquired human infection with Plasmodium cynomolgi. Malaria journal, v. 13, n. 1, p. 68, 2014.

VAL, Fernando et al. Are respiratory complications of Plasmodium vivax malaria na underestimated problem?. Malaria Journal, v. 16, n. 1, p. 495, 2017.

VENTURA, Ana Maria Revorêdo da Silva, Et al. Malária por Plasmodium vivax em crianças e adolescentes - aspectos epidemiológicos, clínicos e laboratoriais. J Pediatr 75: 187-194, 1999.

WASSMER, Samuel C. et al. "Investigating the Pathogenesis of Severe Malaria: A Multidisciplinary and Cross-Geographical Approach." The American Journal of Tropical Medicine and Hygiene 93.3 Suppl (2015): 42-56. PMC. http://doi.org/10.4269/ajtmh.14-0841 Web. 19 June 2017.

Submitted: June, 2020.

Approved: June, 2020.

RC: 52782

Available in: https://www.nucleodoconhecimento.com.br/health/serious-malaria 